University of Nebraska - Lincoln

DigitalCommons@University of Nebraska - Lincoln

Agronomy \& Horticulture -- Faculty Publications

Agronomy and Horticulture Department

2008

Switchgrass Biomass Simulation at Diverse Sites in the Northern Great Plains of the U.S.

Jim R. Kiniry

USDA-ARS, Jim.Kiniry@ars.usda.gov

Marty R. Schmer

USDA-ARS, University of Nebraska-Lincoln, marty.schmer@ars.usda.gov

Kenneth P. Vogel

USDA-ARS, University of Nebraska-Lincoln, kvogel1@unl.edu

Robert B. Mitchell

USDA-ARS, University of Nebraska-Lincoln, rob.mitchell@ars.usda.gov

Follow this and additional works at: https://digitalcommons.unl.edu/agronomyfacpub

Part of the Plant Sciences Commons

Kiniry, Jim R.; Schmer, Marty R.; Vogel, Kenneth P.; and Mitchell, Robert B., "Switchgrass Biomass Simulation at Diverse Sites in the Northern Great Plains of the U.S." (2008). Agronomy \& Horticulture -Faculty Publications. 549.

https://digitalcommons.unl.edu/agronomyfacpub/549

This Article is brought to you for free and open access by the Agronomy and Horticulture Department at DigitalCommons@University of Nebraska - Lincoln. It has been accepted for inclusion in Agronomy \& Horticulture -Faculty Publications by an authorized administrator of DigitalCommons@University of Nebraska - Lincoln. 


\title{
Switchgrass Biomass Simulation at Diverse Sites in the Northern Great Plains of the U.S.
}

\author{
J. R. Kiniry • M. R. Schmer • K. P. Vogel • R. B. Mitchell
}

Published online: 2 December 2008

(C) Springer Science + Business Media, LLC. 2008

\begin{abstract}
The Agricultural Land Management Alternatives with Numerical Assessment Criteria (ALMANAC) model, originally developed and tested in Texas, needs to be tested for switchgrass (Panicum virgatum L.) simulation in more northerly locations. The Northern Great Plains of the U.S. has regionally adapted native populations of switchgrass and has excellent potential for growing switchgrass as a biofuel crop. The objective of this study was to adjust switchgrass parameters (potential leaf area index (DMLA) and degree days to maturity (PHU)) for northern sites and populations and to validate the model against switchgrass data from diverse sites in this region. Three or 4 years of measured yield data were used from a ten field sites in North Dakota (ND), South Dakota (SD), and Nebraska (NE). ALMANAC realistically simulated mean annual switchgrass yields ranging from means of 4.75 to $9.13 \mathrm{Mg} \mathrm{ha}^{-1}$. Mean simulated yields were within 3\%, $15 \%$, and $9 \%$ of mean measured yields for NE, SD, and $\mathrm{ND}$, respectively. Sensitivity analysis with temperature and rainfall demonstrated variable responses of potential yields depending on whether season duration, soil water, or soil nitrogen was the limiting factor at a site. ALMANAC shows promise as a useful tool for switchgrass evaluation and management in the northern Great Plains and in similar latitudes with low rainfall such as the East European Plain.
\end{abstract}

\footnotetext{
J. R. Kiniry $(\bowtie)$

Grassland Soil and Water Research Laboratory, USDA-ARS, 808 East Blackland Road,

Temple, TX 76502, USA

e-mail: Jim.Kiniry@ars.usda.gov
}

M. R. Schmer $\cdot$ K. P. Vogel $\cdot$ R. B. Mitchell Grain, Forage and Bioenergy Research, USDA-ARS, Lincoln, NE, USA
Keywords Biofuel $\cdot$ Degree days $\cdot$ Leaf area index

\begin{tabular}{|c|c|}
\hline Abbreviations & \\
\hline ALMANAC & Agricultural Land Management \\
\hline & Alternatives with Numerical \\
\hline & Assessment Criteria \\
\hline CRP & Conservation reserve program \\
\hline DMLA & Potential leaf area index \\
\hline $\mathrm{GDD}_{12}$ & Growing degree day, base $12 \mathrm{C}$ \\
\hline LAI & Leaf area index \\
\hline NOAA & National Oceanic and Atmospheric \\
\hline & Administration \\
\hline PHU & Degree days to maturity \\
\hline PLS & Pure live seed \\
\hline R1 stage & Panicle fully emerged from boot \\
\hline R5 stage & Postanthesis \\
\hline RUE & Radiation use efficiency \\
\hline USDA-NRCS & U.S. Department of Agriculture \\
\hline & Natural Resource Conservation Service \\
\hline
\end{tabular}

\section{Introduction}

Switchgrass is a highly productive, perennial grass native to much of North America. It is easily established and provides excellent wildlife habitat, protects against nutrient losses to surface water in runoff, and stabilizes soil thereby preventing soil erosion. As the U.S. and other countries have considered how to best address energy needs and soil conservation, switchgrass has risen to the forefront. Before investing large scale economic and land resources into such perennial grass systems for biomass production, process based simulation models can be used to simulate and compare impacts of different plant production systems such 
as switchgrass, maize (Zea mays L.), and sorghum (Sorghum bicolor (L.) Moench). A simulation model that can be used for parallel analyses of biofuels production efficiency, soil erosion, water quality of runoff, nutrient demands, and water use across a wide geographic region will be valuable for policy planning, environmental assessment, and determination of best management schemes. Processbased simulation models such as ALMANAC [4], that use U. S. Department of Agriculture Natural Resource Conservation Service (USDA-NRCS) soils data and National Oceanic and Atmospheric Administration (NOAA) weather data hold promise as realistic tools that can be implemented across large regions without recalibration.

The ALMANAC model has been extensively tested for semi-arid regions of the southern U.S. First, plant parameters were derived for several warm season native and improved grasses $[8,12]$. The model was effective at simulating biomass production for diverse range sites in Texas [9], for improved pastures and native range sites in Texas [12], and for Alamo switchgrass at several sites in Texas, one site in Louisiana, and one site in Arkansas [5, 11]. Likewise, the model has been validated with maize and sorghum under a wide range of conditions in the U.S. $[6,7,10,22]$.

The purpose of the present study was to assess the performance of the ALMANAC model in simulating switchgrass production in the northern Great Plains from east central Nebraska to northeastern North Dakota, where biomass is often limited by an abbreviated growing season. Standardized input parameters were used, even though these regions were $6.62^{\circ}$ to $14.96^{\circ}$ further north than the northernmost site previously simulated in the southern U.S. for ALMANAC's switchgrass simulation validation. We then conducted sensitivity analyses for three representative sites (one per state) for runoff curve number, rainfall, and temperature. We demonstrate how output from this processbased model can be used to simulate how climate change and runoff curve numbers potentially alter switchgrass yields.

\section{Materials and Methods}

\section{General Model Description}

The ALMANAC model has been described previously, especially as relevant for switchgrass simulation $[4,5]$. The model relies on readily available daily weather data and on the extensive USDA-NRCS soils data. Commonly reported values of daily maximum and minimum temperatures, rainfall, and solar radiation are needed. This enables users to apply the model throughout the U.S. by using publicly accessible soils and climate data. The model uses a daily time step to efficiently simulate an extensive range of management, plant, and soil scenarios. ALMANAC is also capable of rapidly simulating multiple years of plant growth in a few seconds.

The ALMANAC model simulates the processes of plant growth and soil water balance, including light interception by leaves, dry matter production, and partitioning of biomass into grain (in the case of crops). ALMANAC simulates leaf area index, light interception with Beer's law, and potential daily biomass increase with a species-specific value of radiation use efficiency (RUE). The daily increases in leaf area index (LAI) and biomass are reduced when plant available water in the current rooting depth is insufficient to meet potential evapotranspiration. Plant development is temperature driven, with duration of growth stages dependent on degree days. Each plant species has a defined base temperature and optimum temperature. For this study, switchgrass was assumed to have a base temperature of $12^{\circ} \mathrm{C}$ [18] and an optimum temperature of $25^{\circ} \mathrm{C}$.

ALMANAC includes a generic LAI function. The maximum LAI of a crop species at high planting density is input. This potential LAI is reduced as a function of planting density. The development of LAI as a function of fraction of seasonal degree day sum follows a sigmoid curve, with two input parameters defining the curve. Daily increments of LAI growth can be reduced by water stress.

\section{Model Evaluation At Ten Sites}

\section{Demonstration Data Sets}

The data described herein were collected at a total of ten locations across Nebraska (NE), South Dakota (SD), and North Dakota (ND) as described by Schmer et al. [15] and Perrin et al. [14]. Soil types, planting methods, and climatic data are reported in these references. Switchgrass grown as a biomass energy crop would be economically feasible in the ten study locations [20]. Fields were chosen based on characteristics of the region and qualifications in the Conservation Reserve Program. Staff from the USDANRCS in NE, SD, and ND assisted with identifying potential cooperators and field sites. Field size ranged from 3 to 9.5 ha with an average of 6.7 ha. Farm cooperators managed all aspects of crop production and harvest, except at the Nebraska switchgrass fields which were planted by USDA-ARS Lincoln Grain, Forage and Bioenergy Project personnel. Nebraska locations were planted in 2000 with the exception of the Atkinson, NE location being replanted in 2001 because of stand failure caused by drought. The South Dakota and North Dakota locations were established in 2001.

A general set of recommended management practices based on previous small plot research were given to all farm cooperators [19]. These management practices detailed seedbed preparation, planting depth, planting dates, herbicide use, and harvesting dates. Populations selected for each field 
were based on prior research within respective geographical regions. Seeding rates were 322 pure live seed (PLS) $\mathrm{m}^{-2}$. Switchgrass populations used in the study were 'Cavein-Rock', 'Trailblazer', 'Shawnee', and 'Sunburst'. The selected populations were primarily developed for pastures. These data provided an excellent test of switchgrass simulation by ALMANAC due to the diversity of populations, soil types, and climatic conditions. In each case, the model was parameterized by site using the site's soil type and the nearest available weather data. The degree day sums for the grass to mature each year (PHU) (base temperature of $12^{\circ} \mathrm{C}$ for switchgrass) were calculated using temperature data for each site. Standardized PHU values were 1100, 800, and 600 for NE, SD, and ND, respectively. The potential leaf area index (DMLA) was assumed to be 3.3 in all cases, which was lower than the leaf area index used previously in the southern U.S. [5, 11]. All other switchgrass parameters were identical to those used previously.

The model was validated against the measured biomass values for the last 4 years in established stands ( 3 years for Atkinson, NE and Huron, SD due to fewer measured years). Thus, low LAI and low productivity values associated with the initial establishment year were not included in the validation.

At each of the ten sites, biomass yields were estimated in 16 quadrats using a $1 \times 1-\mathrm{m}$ frame in 2000 and a $0.3 \times 3.66$ $\mathrm{m}$ frame $\left(1.1-\mathrm{m}^{2}\right)$ in 2001 to 2006 . Biomass yields were measured at the plant maturity stage of R1 to R5 [13] (panicle fully emerged from boot to postanthesis) or after a killing frost. Total plant biomass within the frame was clipped to a $10-\mathrm{cm}$ stubble height and weighed using a portable electronic scale (Intercomp CS750, Minneapolis, $\mathrm{MN})$. A subsample was taken from each sample site to determine dry mass. After quadrat sampling was conducted, fields were mechanically harvested and baled. Most cooperators chose to harvest at emerged inflorescence to post-anthesis (early to mid-August) in post-establishment years, except for the Bristol, SD and Munich, ND locations, which were harvested after a killing frost.

\section{Sensitivity Analyses at Three Sites}

Three sites were selected for sensitivity analyses: Douglas, NE; Bristol, SD; and Streeter, ND. Thirteen years of measured weather were used for each set of simulations. Mean annual rainfall for the 13 years at these sites were $845 \mathrm{~mm}$ for Douglas (1987-1999), $684 \mathrm{~mm}$ at Bristol (1988-2000), and $609 \mathrm{~mm}$ at Streeter (1989-2001). Initial values for soil moisture and soil nutrients can dramatically affect the simulated switchgrass yields in the first few years of a multi-year simulation. When running long term simulations, such possible sources of error can be avoided by including some additional simulation years at the start of the simulations, to allow soil water and soil nitrogen to stabilize to values more typical of established switchgrass fields. Thus for this study, only the simulations for the last 10 years of the 13 were evaluated. Mean switchgrass yield for the 10 years and associated coefficients of variation (CV) were calculated. The simulations for changing runoff curve number, changing rainfall, and changing temperature all assumed $82 \mathrm{~kg} \mathrm{~N}$ per ha were applied each year. An additional set of simulations were done for each location to investigate rainfall effects with no nitrogen limitation (i.e. altered rainfall, $200 \mathrm{~kg} \mathrm{~N}$ per ha each year).

Changes in each input component were designed to test how the model predicted yield changes over a realistic range of inputs. The runoff curve number [17] is a unitless empirical parameter used to simulate how much water infiltrates into the soil and how much runs off a field. It is determined by the soil hydrologic group, the land use cover, and whether a field is terraced or contour planted. The runoff curve number, initially set to 62 for all three sites, was increased and decreased by five and ten units for a total of five treatments. For rainfall, all daily rainfall values were increased (and decreased) by $10 \%, 20 \%$, and $50 \%$. For temperature, all daily maximum and minimum temperature values were increased (and decreased) by $3^{\circ} \mathrm{C}, 6^{\circ} \mathrm{C}$, and $9^{\circ} \mathrm{C}$.

\section{Results}

\section{Model Evaluation at Ten Sites}

Overall, ALMANAC closely simulated measured average yields, maximum yields, and minimum yields over all locations (Table 1). The average for the mean simulated values over all locations was within $1 \%$ of the overall average measured value. For maximum values, the mean overall mean simulated was only $3 \%$ lower than the overall mean measured value. Likewise, for minimums, the overall mean simulated was only $10 \%$ lower than the overall mean measured.

The mean simulated values for each location were within $15 \%$ of mean measured yields for seven of the ten locations. The means for simulated yields were within $10 \%$ of mean measured yields for three of the four NE sites, for two of the four SD sites, and for one of the two ND sites. The mean simulated yields overall by state were within $3 \%$ of measured for NE, within $15 \%$ for SD, and within $9 \%$ for ND.

The sites with the largest differences between simulated and measured mean yields occurred at intermediate to high rainfall sites. The greatest differences occurred at an intermediate rainfall site in NE (Crofton), the highest rainfall site in SD (Huron), and the higher rainfall site in ND (Munich).

The maximum and minimum simulated yields at each location also were similar to the maximum and minimum measured yields, with maximums showing closer agree- 
Table 1 Measured and simulated values of switchgrass biomass for 4 years (unless otherwise noted) at ten locations

\begin{tabular}{|c|c|c|c|c|c|c|}
\hline \multirow[t]{2}{*}{ Location (mean rain) (mm) } & \multicolumn{2}{|l|}{ Mean } & \multicolumn{2}{|l|}{ Max } & \multicolumn{2}{|l|}{ Min } \\
\hline & $\begin{array}{l}\text { Msrd } \\
\mathrm{Mg} / \mathrm{ha}\end{array}$ & $\operatorname{Sim}(\mathrm{S} / \mathrm{M})$ & Msrd & $\operatorname{Sim}(\mathrm{S} / \mathrm{M})$ & Msrd & $\operatorname{Sim}(\mathrm{S} / \mathrm{M})$ \\
\hline \multicolumn{7}{|l|}{ Nebraska } \\
\hline Douglas (710) & 7.99 & $8.70(1.08)$ & 9.30 & $11.90(1.28)$ & 6.71 & $2.93(0.44)$ \\
\hline Lawrence (670) & 5.98 & $5.46(0.91)$ & 8.11 & $8.86(1.09)$ & 4.46 & $3.24(0.73)$ \\
\hline Atkinson $^{\mathrm{a}}(506)$ & 4.97 & $5.30(1.07)$ & 7.51 & $6.96(0.93)$ & 1.53 & $2.72(1.78)$ \\
\hline Crofton (673) & 6.31 & $5.11(0.83)$ & 7.29 & $5.23(0.72)$ & 4.56 & $4.10(0.90)$ \\
\hline \multicolumn{7}{|l|}{ South Dakota } \\
\hline Bristol (593) & 9.13 & $9.06(0.99)$ & 11.96 & $11.24(0.94)$ & 7.26 & $6.47(0.89)$ \\
\hline High (557) & 4.75 & $5.21(1.10)$ & 8.48 & $8.00(0.94)$ & 1.12 & $2.94(2.63)$ \\
\hline Ethan $(710)$ & 5.25 & $5.81(1.11)$ & 7.89 & $7.56(0.96)$ & 2.44 & $3.39(1.39)$ \\
\hline Huron $^{\mathrm{a}}$ (723) & 6.01 & $7.23(1.39)$ & 8.65 & $9.31(1.08)$ & 4.85 & $4.87(1.00)$ \\
\hline \multicolumn{7}{|l|}{ North Dakota } \\
\hline Streeter $(440)$ & 5.63 & $5.04(0.90)$ & 7.42 & $7.87(1.06)$ & 4.61 & $3.52(0.76)$ \\
\hline Munich (531) & 6.61 & $5.58(0.84)$ & 9.79 & $6.46(0.66)$ & 4.63 & $4.21(0.91)$ \\
\hline Overall means & 6.26 & $6.25(1.00)$ & 8.64 & $8.34(0.97)$ & 4.26 & $3.84(0.90)$ \\
\hline
\end{tabular}

The ALMANAC model was used for simulations

Msrd measured, Sim simulated

${ }^{a}$ Only 3 years of values were simulated, due to fewer numbers of measured years

ment than minimums. For the maximums, the simulated values were within $15 \%$ of measured values in seven of ten locations. Only four of the ten locations had minimum simulated values within $15 \%$ of measured minimums.

The average maximum simulated yield was within $1 \%$ of the average maximum measured yield in NE, within $2 \%$ in $\mathrm{SD}$, and within $11 \%$ in ND. The average simulated minimum value was within $4 \%$ of average measured in $\mathrm{NE}, 48 \%$ greater in $\mathrm{SD}$, and $14 \%$ less in ND.

\section{Sensitivity Analyses at Three Sites}

Runoff curve number had little effect on yields in these shortseason, low rainfall locations. This contrasts with the results of Yun Xie et al. [23], which showed that runoff curve number had a major impact on ALMANAC's simulated maize and sorghum yields for eight Texas counties. Increasing or decreasing curve number by ten units always showed less than $10 \%$ changes in yield and usually less than $5 \%$ (Table 2). These results demonstrate that the partitioning of rainfall between runoff and infiltration is relatively unimportant in such low rainfall environments.

For the two wetter locations, increasing temperature by $3^{\circ} \mathrm{C}$ resulted in a $10-11 \%$ increase in mean grass yield, with no further increases in yield when temperature was increased by $6^{\circ} \mathrm{C}$. A $9^{\circ} \mathrm{C}$ increase in temperature decreased yields by $32 \%$ and $41 \%$ at the Douglas and Bristol sites, respectively. For the third, more arid location in Streeter, all increases in temperature resulted in grass yield reductions, with the $9^{\circ} \mathrm{C}$ increase causing a $51 \%$ reduction in mean yield. Temperature reductions decreased mean grass yields, with the $9{ }^{\circ} \mathrm{C}$ temperature decrease causing 50\% (Douglas), 89\% (Bristol), and $97 \%$ (Streeter) reductions in mean grass yield.

When only $82 \mathrm{~kg} \mathrm{~N} \mathrm{ha}^{-1}$ year $^{-1}$ was applied, the increased rainfall for the first two locations caused $\mathrm{N}$ deficiency to have a larger impact on grass yield than did the decreased drought, resulting in slight decreases in mean grass yield. The third, more drought limited location did show yield increases with increased rainfall amounts. When $200 \mathrm{~kg} \mathrm{~N} \mathrm{ha}^{-1}$ year $^{-1}$ was applied, the $\mathrm{N}$ deficiency was not as important for the first and third locations, where mean grass yields increased with each additional increment of rainfall. There was little effect of increased rainfall on yield in the Bristol location.

In contrast, decreased rainfall amounts for the $82 \mathrm{~kg} \mathrm{~N}$ per ha per year simulations usually showed decreased grass yields, with the most severe drought (50\% reduction) caused a decrease in mean simulated grass yields by $23 \%$, $25 \%$, and $60 \%$ for the three locations. For the $200 \mathrm{~kg} \mathrm{~N}$ per ha per year simulations, decreased rainfall showed similar grass yield decreases for the Douglas location, but less drastic reductions for the other two.

\section{Discussion}

The ALMANAC model, with its derived parameters for the southern Great Plains and now the northern Great Plains of the U.S., offers utility as a tool for addressing a number of important environmental, economic, and food supply 
Table 2 Effects of varying inputs on simulated values of switchgrass biomass for 10 years at three locations

\begin{tabular}{|c|c|c|c|}
\hline & Douglas, NE & Bristol, SD & Streeter, ND \\
\hline & Mean $(\mathrm{CV} \%)$ & Mean (CV\%) & Mean $(\mathrm{CV} \%)$ \\
\hline & \multicolumn{3}{|l|}{$\mathrm{Mg} / \mathrm{ha}$} \\
\hline \multicolumn{4}{|c|}{ Runoff curve number } \\
\hline 62 (original) & $7.44(23)$ & $6.85(56)$ & $6.56(36)$ \\
\hline 67 & $7.36(26)$ & $6.94(56)$ & $6.35(36)$ \\
\hline 72 & $7.28(31)$ & $6.99(53)$ & $6.20(36)$ \\
\hline 57 & $7.49(21)$ & $6.77(54)$ & $6.65(36)$ \\
\hline 52 & $7.47(23)$ & $6.70(54)$ & $6.72(36)$ \\
\hline \multicolumn{4}{|l|}{ Temperature } \\
\hline Original values & $7.44(23)$ & $6.85(56)$ & $6.56(36)$ \\
\hline$+3 \mathrm{C}$ & $8.21(23)$ & $7.63(23)$ & $5.65(49)$ \\
\hline$+6 \mathrm{C}$ & $7.31(34)$ & $6.87(29)$ & $4.55(53)$ \\
\hline$+9 \mathrm{C}$ & $5.04(68)$ & $4.07(67)$ & $3.20(65)$ \\
\hline$-3 \mathrm{C}$ & $7.12(20)$ & $5.93(45)$ & $5.13(44)$ \\
\hline$-6 \mathrm{C}$ & $6.78(24)$ & $4.00(46)$ & $2.65(71)$ \\
\hline$-9 \mathrm{C}$ & $3.71(49)$ & $0.78(105)$ & $0.17(166)$ \\
\hline \multicolumn{4}{|c|}{ Rainfall (82 kg N per ha per year applied) } \\
\hline Original values & $7.44(23)$ & $6.85(56)$ & $6.56(36)$ \\
\hline$+10 \%$ & $7.39(25)$ & $6.70(51)$ & $7.31(38)$ \\
\hline$+20 \%$ & $7.28(31)$ & $6.64(49)$ & $7.99(39)$ \\
\hline$+50 \%$ & $7.10(62)$ & $6.56(48)$ & $9.34(40)$ \\
\hline$-10 \%$ & $7.38(30)$ & $6.20(62)$ & $5.74(34)$ \\
\hline$-20 \%$ & $7.78(24)$ & $6.05(67)$ & $4.84(33)$ \\
\hline$-50 \%$ & $5.76(26)$ & $5.57(51)$ & $2.61(37)$ \\
\hline \multicolumn{4}{|c|}{ Rainfall (200 kg N per ha per year applied) } \\
\hline Original values & $12.66(14)$ & $10.14(28)$ & $6.48(35)$ \\
\hline$+10 \%$ & $13.17(15)$ & $10.33(27)$ & $7.26(37)$ \\
\hline$+20 \%$ & $13.73(13)$ & $10.37(27)$ & $7.94(39)$ \\
\hline$+50 \%$ & $14.20(15)$ & $9.90(29)$ & $9.34(40)$ \\
\hline$-10 \%$ & $11.83(17)$ & $8.26(46)$ & $5.63(34)$ \\
\hline$-20 \%$ & $10.66(17)$ & $7.65(44)$ & $4.83(33)$ \\
\hline$-50 \%$ & $5.61(26)$ & $5.71(47)$ & $2.61(37)$ \\
\hline
\end{tabular}

The ALMANAC model was used for simulations

related issues. The model can simulate soil erosion and nutrient losses for maize, sorghum, and switchgrass at any field site under any production system. The model can simulate long-term plant productivity and stability, to address concerns about the land area needed to supply ethanol producing facilities and the sustainability of a given cropping system. Information derived with this model will benefit economists, governmental policy planners, agronomists, and agricultural producers. It will be a valuable tool to determine tradeoffs between biofuel production, economic inputs, and environmental costs. The ALMANAC process-based model differs in form and utility from economic models previously used to simulate switchgrass such as POLYSIS [16] or BIOCOST [20, 21]. The former model was developed for evaluating regional crop production economics. BIOCOST generates budgets to calculate regional and local costs of producing bioenergy crops.
As shown in this study, ALMANAC realistically predicts switchgrass biomass production in the northern Great Plains of the U.S. The results compare favorably with simulation results for Texas, Louisiana, and Arkansas $[5,11]$. In the first study, ALMANAC's simulated switchgrass yields differed from measured values by $0.4 \%$ to $15 \%$. In the second study, simulated switchgrass yields differed from measured values by $0.5 \%$ to $1.8 \%$. In the present study, by changing two parameters (potential LAI and degree days to maturity) the model realistically simulated biomass yield at diverse sites in ND, SD, and NE. This process based model will be useful for predicting switchgrass responses to temperature and precipitation variability across the U.S. The varying importance of runoff curve number in these sites with different rainfall and with different lengths of growing season indicates the relative importance of this key hydrologic variable. This paper provides realistic parameters for these northern 
switchgrass types for future applications and for future simulation and validation research.

The duration of growth of a given switchgrass population at a given latitude is temperature driven, with photoperiod having a variable effect among populations. As discussed above, using degree days, a given site can be characterized by its mean summed $\mathrm{GDD}_{12}$ for switchgrass. Photoperiod affects populations by shortening the growth duration to less than potential for a site as northern populations are moved southward or by lengthening the growth cycle such that a population may not reach flowering or maturity, as southern populations are moved northward. This has been investigated in detail with multilocation studies with diverse sets of switchgrass populations [1, 2]. Given the complexities of plant responsiveness, the ALMANAC model, with its simple phenological routine, performed surprisingly well. Photoperiod responses were accounted for indirectly by adjusting the $\mathrm{GDD}_{12}$ sum for each latitude.

The sensitivity analyses in this study revealed some interesting responses to temperature and rainfall. Changes in temperature caused different simulated yields in these northern, often temperature-limited, locations. Two conflicting processes may explain some of the results. As temperatures increase, plants may increase water use, leading to more drastic drought limitations to grass yield. When temperatures decrease sufficiently, in such northerly locations, shortened growing seasons can reduce grass yields. Likewise, increased rainfall also leads to two different competing processes affecting grass yields. While increased rainfall decreases drought stress, it also results in more nitrogen loss through leaching and in the runoff, so increased nitrogen deficiency.

Future work with this model should involve parameter derivation for the most common individual switchgrass populations and parameter derivation and model validation with other biofuel species such as Miscanthus (Miscanthus $\mathrm{x}$ giganteus) [3]. The ability of the model to simulate diverse species with a common framework of soils and weather make it an invaluable tool as other plant species are considered for biofuel production.

\section{References}

1. Casler MD, Vogel KP, Taliferro CM, Wynia RL (2004) Latitudinal adaptation of switchgrass populations. Crop Sci 44:293-303

2. Casler MD, Vogel KP, Taliaferro CM, Ehlke NJ, Berdhal JD, Brummer EC, Kallenbach RI, West CP (2007) Latitudinal and longitudinal adaptation of switchgrass populations. Crop Sci 47:2249-2260
3. Heaton EA, Dohleman FG, Long SP (2008) Meeting US biofuel goals with less land: the potential of Miscanthus. Glob Chang Biol 14:2000-2014

4. Kiniry JR, Williams JR, Gassman PW, Debaeke P (1992) A general, process-oriented model for two competing plant species. Trans ASAE 35(3):801-810

5. Kiniry JR, Sanderson MA, Williams JR, Tischler CR, Hussey MA, Ocumpaugh WR, Read JC, Van Esbroeck G, Reed RL (1996) Simulating Alamo switchgrass with the ALMANAC model. Agron J 88:602-606

6. Kiniry JR, Williams JR, Vanderlip RL, Atwood JD, Reicosky DC, Mulliken J, Cox WJ, Mascagni HJ, Hollinger SE, Wiebold WJ (1997) Evaluation of two maize models for nine U.S. locations. Agron J 89(3):421-426

7. Kiniry JR, Bockholt AJ (1998) Maize and sorghum simulation in diverse Texas environments. Agron J 90:682-687

8. Kiniry JR, Tischler CR, Van Esbroech GA (1999) Radiation use efficiency and leaf $\mathrm{CO}_{2}$ exchange for diverse $\mathrm{C}_{4}$ grasses. Biomass Bioenergy 17:95-112

9. Kiniry JR, Sanchez H, Greenwade J, Seidensticker E, Bell JR, Pringle F, Peacock G Jr, Rives J (2002) Simulating grass productivity on diverse range sites in Texas. J Soil Water Conserv 57:144-150

10. Kiniry JR, Bean B, Xie Y, Chen P (2004) Maize yield potential: critical processes and simulation modeling in a high-yielding environment. Agric Syst 82:45-56

11. Kiniry JR, Cassida KA, Hussey MA, Muir JP, Ocumpaugh WR, Read JC, Reed RL, Sanderson MA, Venuto BC, Williams JR (2005) Switchgrass simulation by the ALMANAC model at diverse sites in the southern U.S. Biomass and Bioenergy 29:419-425

12. Kiniry JR, Burson BL, Evers GW, Williams JR, Sanchez H, Wade C, Featherston JW, Greenwade J (2007) Coastal bermudagrass, bahiagrass, and native range simulation at diverse sites in Texas. Agron $\mathrm{J}$ 99:450-461

13. Moore KJ, Moser LE, Vogel KP, Waller SS, Johnson BE, Pedersen JF (1991) Describing and quantifying growth stages of perennial forage grasses. Agron J 83:1073-1077

14. Perrin RK, Vogel KP, Schmer MR, Mitchell RB (2008) Farmscale production costs of switchgrass for biomass. Bioenerg Res 1:91-97

15. Schmer MR, Vogel KP, Mitchell RB, Moser LE, Eskridge KM, Perrin RK (2006) Establishment stand thresholds for switchgrass grown as a bioenergy crop. Crop Sci 46:157-161

16. Ugarte DGD, Ray DE (2000) Biomass and bioenergy applications of the POLYSYS modeling framework. Biomass Bioenergy 18:291-308

17. USDA-SCS (1972) National engineering handbook. Section 4, hydrology. USDA-SCS, Washington, DC, USA

18. Van Esbroeck GA (1996) Genetic control of switchgrass growth and development. Ph.D. dissertation, Texas A\&M University

19. Vogel KP (2004) Switchgrass. In: Moser LE et al (ed) Warm-season (C4) grasses. Agronomy monograph no. 45. ASA-CSSA-SSSA, Madison, WI, pp 561-587

20. Walsh ME (1998) U.S. bioenergy crop economic analyses: Status and needs. Biomass Bioenergy 14:341-350

21. Walsh ME (2000) Method to estimate bioenergy crop feedstock supply curves. Biomass Bioenergy 18(4):283-289

22. Xie Y, Kiniry JR, Nedbalek V, Rosenthal WD (2001) Maize and sorghum simulations with CERES-Maize, SORKAM, and ALMANAC under water-limiting conditions. Agron. J. 93:1148-1155

23. Xie Y, Kiniry JR, Williams JR (2003) The ALMANAC model's sensitivity to input variables. Agric Syst 78:1-16 